\title{
Experimental Study on the Use of Rice Husk Ash as Partial Cement Replacement in Aerated Concrete
}

\author{
Abdullah Saand \\ Department of Civil Engineering, \\ Quaid-e-Awam University of Engineering, Science \\ \&Technology, Nawabshah, Sindh, Pakistan \\ abdullah@quest.edu.pk \\ Manthar Ali Keerio \\ Department of Civil Engineering, \\ Quaid-e-Awam University of Engineering, Science \& \\ Technology, Nawabshah, Sindh, Pakistan \\ mantharali99@quest.edu.pk
}

\author{
Tariq Ali \\ Department of Civil Engineering, \\ Quaid-e-Awam University of Engineering, Science \& \\ Technology, Nawabshah, Sindh, Pakistan \\ tariqdehraj@gmail.com \\ Daddan Khan Bangwar \\ Department of Civil Engineering, \\ Quaid-e-Awam University of Engineering, Science \& \\ Technology, Nawabshah, Sindh, Pakistan \\ daddan@quest.edu.pk
}

\begin{abstract}
This paper adopts an experimental approach on the use of rice husk ash as a partial replacement of cement in the production of concrete and the consequent effects on density, compressive strength and split tensile strength of the formulated product. Rice husk ash is used as replacement of cement in different dosages of $0 \%, 2.5 \%, 5 \%, 7.5 \%, 10 \%, 12.5 \%$, and $15 \%$. Results showed that $10 \%$ replacement of cement with rice husk ash is optimum. At $10 \%$ replacement of cement with RHA, the density is increased by $\mathbf{5 . 0 2 \%}$, the compressive strength by $\mathbf{2 2 . 2 2 \%}$ and the split tensile strength by $\mathbf{2 0 . 4 5 \%}$ in comparison with control aerated concrete.
\end{abstract}

Keywords-aerated; non-autoclaved; RHA; aluminium powder; autoclaved

\section{INTRODUCTION}

Nowadays, the tendency is towards the use of lightweight materials in building construction that not only help in the structural stability of the structure but also contribute in cost reduction. Aerated concrete, also known as cellular concrete, is a type of lightweight concrete [1]. Aerated concrete is produced by adding aluminum powder in the concrete matrix which generates hydrogen gas in the cement slurry. Aerated concrete is further classified into two main types depending on the nature of curing: one is AAC (autoclave aerated concrete) and the other is NAAC (non-autoclaved aerated concrete) [2-5]. The major advantage of aerated concrete is its light weight which helps in minimizing the self-weight of the structure including foundation and walls. Aerated concrete is also very useful in heat and sound insulation. A wide density range $\left(300 \pm 1800 \mathrm{~kg} / \mathrm{m}^{3}\right)$ of aerated concrete is available and it can be mould and cut into any desired shape. Also it provides structural, partition and insulation flexibility in manufacturing products.

Cement is the most important component in concrete production. But cement production in huge amounts pollutes the environment as it entails huge emissions of $\mathrm{CO}_{2}$ accounting for over $50 \%$ percent of all industrial $\mathrm{CO}_{2}$ emissions. Large numbers of natural resources are required for the production of cement which are not renewable. Waste materials can be used in concrete by partially replacing cement, which not only protects the environment from pollution, but also reduces the cement demand [6]. In such pursuit the properties of aerated concrete incorporated with industrial and agriculture byproducts have been studied. These industrial and agriculture by-products can also improve concrete durability. POFA, blast furnace slag, PFA and rice husk ash, etc., have been used as cement replacement materials [7-10].

In Pakistan, the most abundantly harvested crop is rice. World's annual production of rice is about 5 million tons per year [11]. Three major organic by-products from rice are rice bran, rice straw and rice husk [12]. Rice husk is a waste material which is not useful for animal feeding due to its low protein content. Rice husk contains a high concentration of silica, generally more than $80 \%-85 \%$ [13]. Rice husk, in actual, is the outer layer of the rice grain, produced by the rice milling industries. Rice husk consists of 30\% lignin group, $20 \%$ silica and about $40 \%$ cellulose. On combustion, the cellulose-lignin matrix of rice husk burns off and leaves a porous silica skeleton only. Hence, rice husk ash (RHA) contains a large amount of silica [11-15]. RHA is fine powder having a high surface area, produced when porous silica skeleton of rice is grinded [16]. The chemical composition of RHA is attributed to calcinations process [17]. RHA can be utilized as a mineral admixture for cement and concrete $[18,19]$ and its cementitious properties mostly depend upon its source [20-22].

\section{MATERIALS USED}

In this study aerated concrete mixture was produced by using RHA, Ordinary Portland Cement, quartz sand, water, and aluminum powder. OPC complies with the Type I Portland 
Cement as in ASTM C150 (1992) and BS 12 (1991). The rice husk was collected from a rice mill and the RHA was synthesized in the laboratory with the use of an electric furnace for an hour at $500^{\circ} \mathrm{C}$. It was grounded before being passed through a No. 325 sieve. Approximately $76.75 \%$ of the content of RHA is oxide (i.e. alumina, iron oxide and silica). The RHA follows the specifications of ASTM C 618. Over the entire casting, sand passing from $600 \mu \mathrm{m}$ was used. Aluminum powder was used as an aerating agent.

TABLE I. OPC AND RHA PHYSICAL CHARACTERISTICS

\begin{tabular}{|c|c|}
\hline Sample & Specific gravity \\
\hline OPC & 3.15 \\
\hline RHA & 2.12 \\
\hline
\end{tabular}

\section{EXPERIMENTAL WORK}

Seven different mixes were prepared, including control mix (for details, see Table II). Each mix consisted of 5 samples. At first, cement, sand and RHA were mixed in dry state and then the aluminum powder was mixed properly in that dry mix. After that, water was added properly as per mix requirements, and then cubic moulds of $100 \mathrm{~mm} \times 100 \mathrm{~mm} \times 100 \mathrm{~mm}$ size and cylindrical moulds of size $150 \mathrm{~mm} \times 300 \mathrm{~mm}$ were filled. The moulds were filled up to $80 \%$ and then they were placed for $24 \mathrm{~h}$ in open atmosphere. Pouring expansion started due to aluminum powder and approximately after $3 \mathrm{~h}$, the specimens became rigid, inflexible, hard enough and ready to trim the expanded portion above the top of the specimens. After demoulding, samples were placed in water for curing for the next 28 days. Figures 1 and 2 show the aerated concrete cubical and the aerated concrete cylindrical specimens respectively, before trimming. Before being subjected to compression and splitting tensile testing, the samples were weighed and their density was determined.

TABLE II. MIX PROPORTIONS

\begin{tabular}{|c|c|c|c|c|c|c|}
\hline $\begin{array}{c}\text { Cement } \\
\text { replacement } \\
\text { level (\%) }\end{array}$ & $\begin{array}{c}\text { Mix } \\
\text { proportion }\end{array}$ & $\begin{array}{c}\text { Cement } \\
(\mathbf{K g})\end{array}$ & $\begin{array}{c}\text { RHA } \\
(\mathbf{K g})\end{array}$ & $\begin{array}{c}\text { Sand } \\
(\mathbf{K g})\end{array}$ & $\begin{array}{c}\text { W/C } \\
\text { ratio } \\
(\%)\end{array}$ & $\begin{array}{c}\text { Aluminum } \\
\text { content (\% by } \\
\text { wt. of binder) }\end{array}$ \\
\hline 0.0 & $1: 1$ & 10 & 0 & 10 & 0.60 & 0.5 \\
\hline 2.5 & $1: 1$ & 9.75 & 0.25 & & 0.61 & 0.5 \\
\hline 5.0 & $1: 1$ & 9.5 & 0.5 & & 0.62 & 0.5 \\
\hline 7.5 & $1: 1$ & 9.25 & 0.75 & & 0.63 & 0.5 \\
\hline 10.0 & $1: 1$ & 9.0 & 1.0 & & 0.64 & 0.5 \\
\hline 12.5 & $1: 1$ & 8.75 & 1.25 & & 0.65 & 0.5 \\
\hline 15 & $1: 1$ & 8.5 & 1.5 & & 0.66 & 0.5 \\
\hline
\end{tabular}

\section{RESULTS AND DISCUSSION}

This study aimed to investigate the properties of aerated concrete composite with RHA in order to produce aerated concrete. The specific gravity of OPC is 3.15 , this value indicates that cement particles are heavier than RHA whose specific gravity is 2.12 as mentioned in Table I. The most important characteristic of aerated concrete is its lower density when it is compared with the density of conventional concrete it ranges from $300 \mathrm{~kg} / \mathrm{m}^{3}$ to $1800 \mathrm{~kg} / \mathrm{m}^{3}$. From Table III and Figure 3, it is observed that using RHA in aerated concrete production causes an increase in density. Cement replacement with RHA reduced the aeration process which ultimately increased the density of aerated concrete. Maximum density, $1066 \mathrm{~kg} / \mathrm{m}^{3}$, was found at $10 \%$ RHA replacent (i.e. $5.02 \%$ increase) as compared to the control mix of aerated concrete and then density started decreasing at $12.5 \%$ and $15 \%$ replacement ratios due to the difference between specific gravity values of cement and RHA.

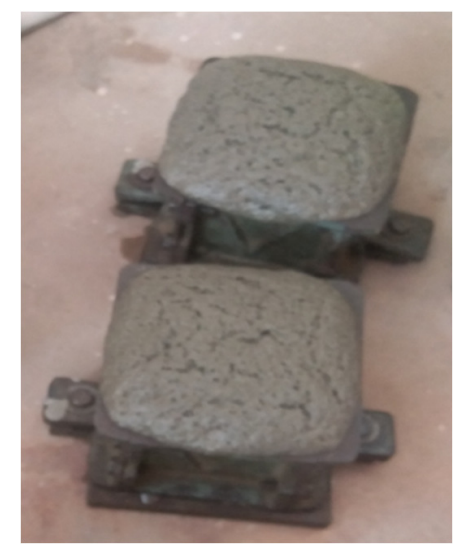

Fig. 1. Aerated concrete cubical specimens before trimming

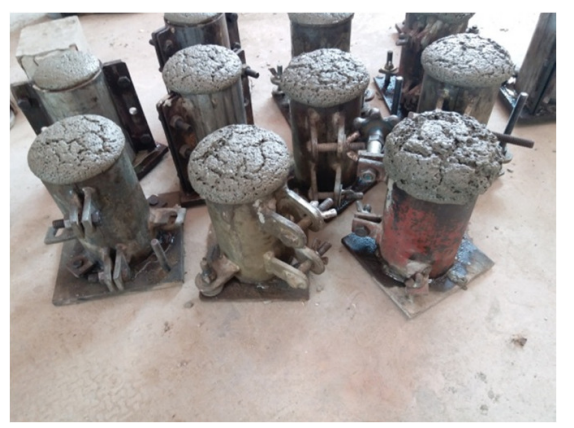

Fig. 2. Aerated concrete cylindrical specimens before trimming

TABLE III. DENSITY AND COMPRESSIVE STRENGTH BY PARTIAL REPLACEMENT OF CEMENT WITH RHA AT 28 DAYS CURING

\begin{tabular}{|c|c|c|c|}
\hline $\begin{array}{c}\text { Aerated } \\
\text { concrete } \mathbf{~ m i x}\end{array}$ & $\begin{array}{c}\text { Density } \\
\left(\mathbf{K g} / \mathbf{m}^{\mathbf{3}}\right)\end{array}$ & $\begin{array}{c}\text { Compressive } \\
\text { strength }(\mathbf{M P a})\end{array}$ & $\begin{array}{c}\text { Split tensile } \\
\text { strength (MPa) }\end{array}$ \\
\hline $0 \%$ & 1015 & 3.6 & 0.44 \\
\hline $2.5 \%$ & 1022 & 3.7 & 0.46 \\
\hline $5 \%$ & 1035 & 3.9 & 0.47 \\
\hline $7.5 \%$ & 1050 & 4.1 & 0.49 \\
\hline $10 \%$ & 1066 & 4.4 & 0.53 \\
\hline $12.5 \%$ & 1060 & 4.2 & 0.51 \\
\hline $15 \%$ & 1056 & 3.8 & 0.49 \\
\hline
\end{tabular}

All the densities found in this research lie in the range of aerated concrete as shown in Table III. It was observed that with the increase in replacement ratio of cement with RHA, the compressive strength and split tensile strength increased due to the pozzolanic properties of RHA. Compressive strength and split tensile strength increased as compared to control mix by the substitution of cement with the RHA from $2.5 \%$ to $10 \%$ and on further substitution of cement, compressive and split tensile strength decreased. At 10\% replacement of cement with RHA, the maximum compressive strength and split tensile strength were found to be $4.4 \mathrm{MPa}$ (22.22\% increase) and $0.53 \mathrm{MPa}(20.45 \%$ increase) respectively as compared to the control the of aerated concrete (Figures 45). 


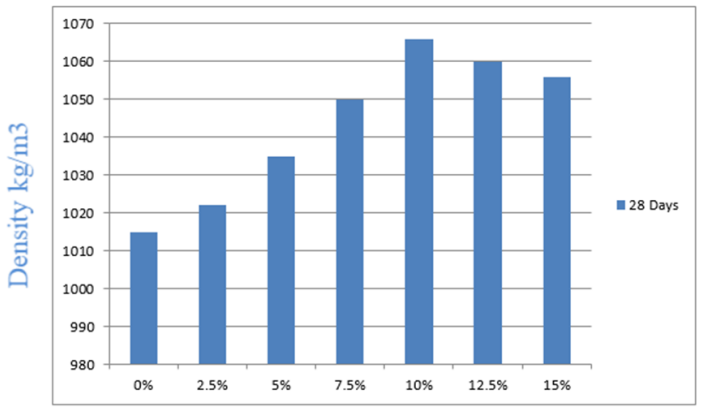

Percentage replacement with RHA

Fig. 3. Density of RHA aerated concrete

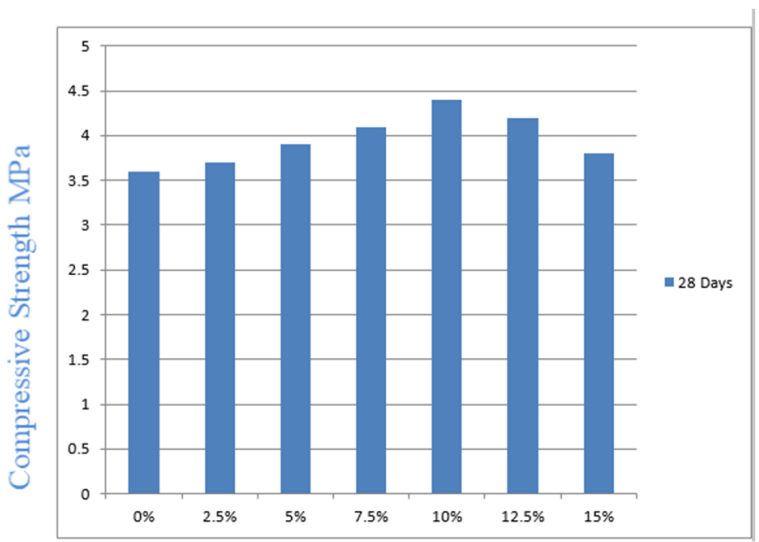

Percentage replacement with RHA

Fig. 4. Compressive strength of RHA aerated concrete

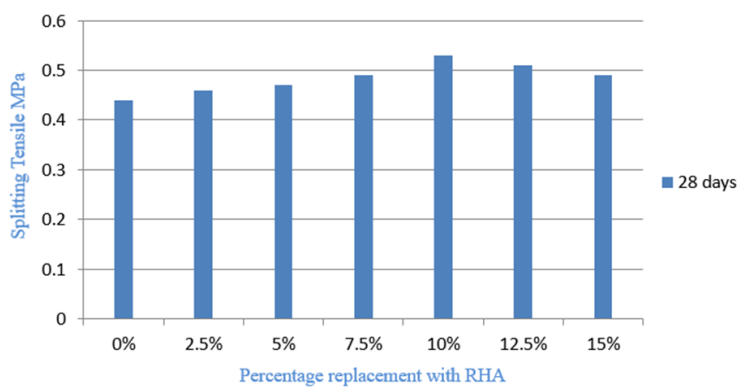

Fig. 5. Split tensile strength of RHA aerated concrete

It is worth noting that with the increase in the RHA percentage, more water was required (the water-binder ratio is shown in Table II). As the quantity of water increased and cement was replaced by RHA in percentages above $10 \%$ in increasing order, the compressive and split tensile strength decreased.

\section{CONCLUSIONS}

This paper mainly focused on the utilization of the waste agricultural material RHA, as a potential replacement of cement in the production of aerated concrete. Based on the research the following conclusions are made:
- The density of modified mixes increased as compared to the control mix by the substitution of cement with RHA from $2.5 \%$ to $10 \%$ and decreased on further substitution. At $10 \%$ replacement, the maximum density was found at $1066 \mathrm{~kg} / \mathrm{m}^{3}$ (5.02\% increase).

- The compressive strength of modified mixes increased with the substitution of cement with RHA from $2.5 \%$ to $10 \%$. On further substitution, the compressive strength decreased. At $10 \%$ replacement, the maximum compressive strength was found at $4.4 \mathrm{MPa}(22.22 \%$ increase $)$.

- Split tensile strength of modified mixes increased as compared to control mix by the substitution of cement with RHA from $2.5 \%$ to $10 \%$ and on further substitution, it decreased. At $10 \%$ replacement of cement with RHA, the maximum split tensile strength was found as $0.53 \mathrm{MPa}$ (20.45\% increase) as compared to the control mix.

- On the basis of conducted parameters of aerated concrete, $10 \%$ replacement of cement with RHA is optimum. At $10 \%$ replacement, a slight increase in density $(5.02 \%)$ and more in compressive and split tensile strength $(22.22 \%$ and $20.45 \%$ respectively) were observed as compared to control aerated concrete.

\section{ACKNOWLEDGEMENT}

The authors acknowledge the Quaid-e-Awam University for the provision of the necessary funds required for this research.

\section{REFERENCES}

[1] A. M. Neville, J. J. Brooks, Concrete Technology, Pearson Education, 2010

[2] L. B. Yen, Study of Water Ingress into Foamed Concrete, MSc Thesis, National University of Singapore, 2006

[3] Z. Li, Advanced Concrete Technology, John Wiley \& Sons, 2011

[4] A. J. Hamad, "Materials, production, properties and application of aerated lightweight concrete: Review", International Journal of Materials Science and Engineering, Vol. 2, No. 2, pp. 152-157, 2014

[5] N. Narayanan, K. Ramamurthy, "Structure and properties of aerated concrete: A review", Cement and Concrete Composites, Vol. 22, No. 5 , pp. 321-329, 2000

[6] T. Mehmannavaz, S. R. Sumadi, M. A. R. Bhutta, M. Samadi, S. M. Sajjadi, "Effect of waste materials in lightweight concrete", Australian Journal of Basic \& Applied Sciences, Vol. 7, No. 11, pp. 513-519, 2013

[7] N. A. Memon, S. R. Sumadi, M. Ramli, "Lightweight aerated concrete incorporating various percentages of slag and PFA", Journal of Applied Sciences, Vol. 6, No. 7, pp. 1560-1565, 2006

[8] N. A. Memon, S. R. Sumadi, M. Ramli, "Ferrocement encased lightweight aerated concrete: A novel approach to produce sandwich composite", Materials Letters, Vol. 61, No. 19-20, pp. 4035-4038, 2007

[9] N. Narayanan, K. Ramamurthy, "Microstructural investigations on aerated concrete", Cement and Concrete Research, Vol. 30, No. 3, pp. 457-464, 2000

[10] P. K. Mehta, "Reducing the environmental impact of concrete", Concrete International, Vol. 23, No. 10, pp. 61-66, 2001

[11] G. R. D. Sensale, "Strength development of concrete with rice husk ash", Cement and Concrete Composites, Vol. 28, No. 2, pp. 158-160, 2006

[12] R. Begum, A. Habib, S. Mostafa, "Effects of rice husk ash on the nonautoclaved aerated concrete", International Journal of Engineering Innovations and Research, Vol. 3, No. 1, pp. 116-120, 2014

[13] R. Siddique, Waste Materials and By-Products in Concrete, Springer, 2008 
[14] V. Sata, C. Jaturapitukkul, K. Kiattikomol, "Influence of pozzolan from various by-product materials on mechanical properties of high-strength concrete", Construction and Building Materials, Vol. 21, No. 7, pp. 1589-1598, 2007

[15] P. Chindaprasirt, C. Jaturapitukkul, U. Rattanasak, "Influence of fineness of rice husk ash and additives on the properties of lightweight aggregate”, Fuel, Vol. 88, No. 1, pp. 158-162, 2009

[16] S. Aroni, "On energy conservation characteristics of autoclaved aerate concrete", Materials and Structures, Vol. 23, No. 1, pp. 68-77, 1990

[17] G. R. D. Sensale, "Effect of rice-husk ash on the durability of cementitious materials", Cement and Concrete Composites, Vol. 32, No. 9, pp. 718-725, 2010

[18] P. K. Mehta, Rice-Husk Ash-A Unique Supplementary Cementing Material, Advances in Concrete Technology, 1992

[19] 73-SBC RILEM Committee, "Final report siliceous by-products for use inconcrete", Material and Structures, Vol. 21, No. 1, pp. 69-80, 1988

[20] V. M. Malhotra, P. K. Mehta, Pozzolanic and Cementitious Materials, Gordon and Breach Publishers, 1996

[21] J. James, M. S. Rao, "Reactivity of rice husk ash", Cement and Concrete Research, Vol. 16, No. 3, pp. 296-302, 1986

[22] K. Kunchariyakun, S. Asavapisit, K. Sombatsompop, "Properties of autoclaved aerated concrete incorporating rice husk ash as a partial replacement for fine aggregate", Cement and Concrete Composites, Vol. 55, pp. 11-16, 2015 